\begin{tabular}{cc}
\hline Revista de & Journal of Integrated \\
GESTÃO COSTEIRA Integrada COSTAL ZONE MANAGEMENT \\
\hline \hline
\end{tabular}

\title{
Methodological proposal for characterization of marine geodiversity in the South Atlantic: Vitória-Trindade Ridge and adjacent areas, Southeast of Brazil*
}

\author{
Maria Adelaide Mansini Maia ${ }^{\circledR}$, a ; João Wagner de Alencar Castro ${ }^{\text {b }}$
}

\begin{abstract}
Knowledge of marine geodiversity aids in the understanding of geological processes that operate in the marine domain. These processes are responsible for the creation of landscapes, interference in ocean current patterns and sediment deposition, formation of mineral deposits, triggering of geological hazards and biodiversity development, among other aspects. Marine geodiversity surveys enable an integrated perspective of the dynamics and geological processes occurring in the continental margins and sea basins. They can provide essential information regarding the suitability and limitations of this region during considerations of numerous possibilities for use.

This study was aimed at developing a regional-scale model for characterizing marine geodiversity in the Vitória-Trindade Volcanic Seamount Ridge and its adjacent marine areas in the South Atlantic off the coast of southeastern Brazil. The adopted methodology involved defining marine geodiversity compartments in a geographic information system environment by integrating and analyzing spatial variables obtained from bathymetric, geological, and geophysical data as well as by using information available from the literature, government databases, and research institutions. Five representative aspects of geodiversity in the study area were defined, namely, scientific, environmental, economic, academic, and geotouristic characteristics.

From this analysis, 13 key areas with peculiar aspects of geodiversity, geoheritage, and potential use were selected for further analyses. For the selected areas, records of scientific and educational interest about the geological history of the opening of the South Atlantic Ocean and formation of the Brazilian continental margin were reviewed and potential areas of use aimed at geotourism and mineral exploration were examined. Restrictions on use related to geologic hazards and anthropogenic actions as well as the legal, technological, and financial aspects arising from the occupation of these spaces were discussed.

The information obtained aims to support the actions of the Brazilian government for marine spatial planning with regard to the exploitation of resources and geoconservation of the unique aspects of the geological history of Brazil and the most susceptible habitats. This work also serves as an orientation framework for future surveys of geodiversity in other marine regions.
\end{abstract}

Keywords: Geoheritage, Marine landscapes, Geographic information system, Land management, Brazilian Exclusive Economic Zone.

\section{RESUMO}

Proposta Metodológica para caracterização da geodiversidade marinha no Atlântico Sul: Cadeia Vitória-Trindade e áreas adjacentes, sudeste do Brasil.

O conhecimento de geodiversidade marinha torna possível a compreensão dos processos geológicos que atuam no domínio marinho, responsáveis por gerar paisagens, interferir nos padrões de circulação das correntes oceânicas e da deposição sedimentar, formar depósitos minerais, desencadear fenômenos causadores do risco geológico e subsidiar ao desenvolvimento

(a) Corresponding author to whom correspondence should be addressed.

${ }^{a}$ Geological Survey of Brazil (Serviço Geológico do Brasil-CPRM), Avenida Pasteur, 404, Urca 22290-255, Rio de Janeiro, Brazil. e-mail: <adelaide.maia@cprm.gov.br>

${ }^{\mathrm{b}}$ Universidade Federal de Rio de Janeiro (UFRJ), Laboratório de Geologia Costeira, Sedimentologia e Meio Ambiente, Museu, Quinta da Boa Vista, São Cristóvão 20940-040, Rio de Janeiro, Brazil, e-mail: <jwcastro@gmail.com>

Submission: 2 JUN 2014; Peer review: 8 JUK 2014; Revised: 26 NOV 2014; Accepted: 30 NOV 2014; Available on-line: 1 DEC 2014 This article contains supporting information online at http://www.aprh.pt/rgci/pdf/rgci-519_Maia_Supporting-Information.pdf 
da biodiversidade, dentre outros aspectos. Levantamentos da geodiversidade marinha possibilitam uma visão integrada das dinâmicas e processos geológicos ocorrentes nas margens continentais e bacias oceânicas, podendo oferecer informações fundamentais quanto às adequações e limitações desse meio perante as múltiplas possibilidades de uso. O presente trabalho teve como objetivo desenvolver um modelo, em escala regional, para caracterização da geodiversidade marinha, tendo como área-piloto a Cadeia de Montes Vulcânicos Submarinos de Vitória-Trindade e áreas adjacentes, situada no Atlântico Sul, sudeste do Brasil. A metodologia adotada compreendeu a definição de compartimentos da geodiversidade marinha, em ambiente de sistema de informação geográfica, através da integração e análise de variáveis espaciais resultantes de dados batimétricos, geológicos, geofísicos e de uso e ocupação, disponíveis na literatura e em bancos de dados governamentais e de instituição de pesquisas. Foram definidos 5 compartimentos representativos da geodiversidade da área de estudo, os quais foram atribuídos valores científicos, ambientais, econômicos, educativos e geoturísticos. Dessa análise, resultou a seleção de 13 áreas-chaves representativas de aspectos peculiares da geodiversidade marinha e do patrimônio geológico e potencial de uso a elas associado. As áreas selecionadas incluem registros de interesse científico e educativo sobre a história geológica da abertura do Oceano Atlântico Sul e formação da Margem Continental Brasileira, áreas potenciais de uso voltadas ao geoturismo e aproveitamento mineral. Foram abordadas restrições ao uso relacionado ao risco geológico; ações antrópicas; aspectos legais, tecnológicos e financeiros decorrentes da ocupação desses espaços. As informações obtidas visam subsidiar as ações governamentais brasileiras para o ordenamento do território marinho quanto ao aproveitamento de seus recursos e geoconservação dos aspectos singulares da história geológica brasileira e dos habitats mais suscetíveis. Constitui dessa forma um orientativo para futuros levantamentos da geodiversidade em regiões marinhas.

Palavras-chaves: Patrimônio geológico, Paisagens marinhas, Sistema de Informação Geográfica, Planejamento territorial, Zona Econômica Exclusiva Brasileira.

\section{Introduction}

\subsection{Framework}

The term "geodiversity" emerged in the 1990s as a counterpart to "biodiversity," and it defines the abiotic component of nature (Gray, 2004, 2008). Over the following years, the concept of geodiversity has been increasingly used, which has helped it to take on the same importance as the concept of biodiversity. However, in the marine realm, there have been few studies related to geoheritage and geoconservation. Relevant research to date has been restricted to coastal areas and submerged portions of oceanic islands and the adjacent seafloor (Nunes et al., 2007; Felton, 2010; Booth \& Brayson, 2011; Kaskela et al., 2012; Lima et al., 2014).

The term marine geodiversity refers to the abiotic variety of nature in the seabed; this abiotic variety is a result of geological processes such as tectonism, magmatic volcanism, sedimentary deposition, and modification by marine geomorphological processes.

Studies on geodiversity focusing directly on the seabed are relatively recent; such studies have been conducted in the Baltic Sea, Gulf of Finland, and in seas off the United Kingdom. In general, such studies are intended to document relationships between biodiversity and geodiversity and to identify areas where both marine biotic and abiotic aspects have to be protected (Rovere et al., 2010; Gordon \& Barron, 2011; Burek et al., 2012; Brooks et al., 2012).

\subsubsection{Geodiversity approach in the Brazilian territory}

In Brazil, the application of the concepts of geodiversity and geoheritage and the corresponding methodology is in the consolidation phase. Studies that have been conducted in this region have focused on the physical environment of the continental, coastal, and island portions in order to promote territorial management policies by government agencies and support the work of research institutions and researchers dedicated to geoheritage, geoconservation, and geotourism issues (Schmitt \& Mansur, 2001; Nascimento et al., 2008; Mansur \& Carvalho, 2011).

The most relevant initiatives are as follows:

- registration of geological sites at the worldwide level by the Brazilian Commission on Geological and Palaeobiological Sites (Comissão Brasileira dos Sítios Geológicos e Paleobiológicos-SIGEP) (sigep. cprm.gov.br);

- Geological Paths Project of Rio de Janeiro State (Projeto Caminhos Geológicos), which works for the promotion and preservation of geoheritage through educational signboards (www.caminhos geologicos.rj.gov.br);

- Geological and Paleontological Site Project of Paraná State (Projeto Sítio Geológico e Paleontológico do Paraná) (www.mineropar.pr.gov.br);

- Geological Monuments Project of São Paulo State (Projeto Monumentos Geológicos do Estado de São Paulo) (www.igeo logico.sp.gov.br);

- Geoparks Project (Projeto Geoparques), which is conducted by the Geological Survey of Brazil (Serviço Geológico do Brasil/Companhia de Pesquisa de Recursos Minerais-CPRM) and aims to describe and identify areas with potential for future geoparks in the Brazilian territory (www.cprm.gov. br); and 
- Geodiversity Surveying Program (Programa de Levantamento da Geodiversidade), which is conducted by the CPRM in all Brazilian states and border areas (www.cprm.gov.br).

In Brazil, Maia et al. (2012) were the first to propose an approach based on the "marine geodiversity" theme. In their work, a preliminary view of the physiographic subdivisions and the geological characteristics of the Vitória-Trindade Volcanic Seamount Ridge and its adjacent region were presented. In a study on the geoconservation of Trindade Island, Pires et al. (2013) stressed the importance of the island and its significant heritage value because of the rarity of the rocks and volcanicmagmatic structures present there.

\subsection{Objective}

This study aims to characterize the marine geodiversity in the Vitória - Trindade Ridge and adjacent marine areas at a regional scale $(1: 2,500,000)$ by means of geoprocessing techniques made possible by a Geographic Information System (GIS). Key areas with aspects relevant to geodiversity are first identified, and then analyses of the main geoheritage aspects and their potential for use are presented.

\section{Study area}

\subsection{Location}

The study area extends to about $740,000 \mathrm{~km}^{2}$, and it covers the Vitória - Trindade Ridge and other physiographic features in the 200 nautical miles of the Brazilian Exclusive Economic Zone (EEZ) and an area proposed by the Brazilian government for the expansion of the Brazilian Legal Continental Shelf Brazilian. The Vitória - Trindade Ridge is located in the South Atlantic between the latitudes of $20^{\circ} 29^{\prime}-20^{\circ} 32^{\prime} \mathrm{S}$ and the longitudes of $29^{\circ} 17^{\prime}-29^{\circ} 21^{\prime} \mathrm{W}$; it lies along the coast of Espírito Santo State, Brazil (Figure 1).

\subsection{Vitória-Trindade Ridge}

The Vitória - Trindade Ridge consists of approximately 30 seamounts and submarine banks (Besnard bank, Champlain seamount, Vitória seamount, Congress bank, Montague seamount, Jaseur seamount, Colúmbia bank, Davis bank, Dogaressa bank, Colúmbia sea-mount, and other unnamed elevations) that are morphologically recognized as volcanic buildings, and at least 17 are submerged volcanoes with heights exceeding $2,500 \mathrm{~m}$ (Motoky et al., 2012). The outcropping portion is located at the western end of the ridge about $600 \mathrm{~m}$ above sea level; this area corresponds to Trindade Island $\left(10.2 \mathrm{~km}^{2}\right)$ and the Martin Vaz Archipelago $\left(0.3 \mathrm{~km}^{2}\right)$.

Some studies indicate that the origin of the Vitória Trindade Ridge was associated with Cenozoic tec- tonomagmatic activities that occurred during South American plate displacement under the action of a mantle plume that is currently located under Trindade Island and the Martin Vaz Archipelago (Thomaz Filho \& Rodrigues, 1999; Skolotnev et al., 2011). Alves et al. (2006) relates the Vitória - Trindade Ridge origin to the Vitória-Trindade Fracture Zone, through which magma from the mantle might have ascended to the surface.

\section{Methodological proposal}

The Brazilian Continental Margin (BCM) and adjacent areas have been surveyed by the Brazilian Government for the purpose of extending maritime legal domains. The existing studies are generally on a regional scale and pertain to a specific theme, mainly related to the oil industry in the areas of marginal sedimentary basins. Hence, little is known about the Brazilian Ocean Basins (BOB).

In the absence of systematic information on the physical environment in the study area, a proposal was made to construct a regional-scale marine geodiversity characterization model through bibliographic compilations and integration of environmental, bathymetric, geological, and geophysical data including data used in GISs. In order to exemplify the geodiversity of the study area, which ranges from shallow portions of the $\mathrm{BCM}$ to the ultra-deep water regions of the BOB, key areas that represent this geodiversity, geoheritage, and associated potential use were evaluated.

This work proposal was divided into five main stages, as shown in Figure 2, and the stages were as follows: (1) literature review and general data acquisition; (2) organization of data in the GIS; (3) generation of products and auxiliary analyses; (4) definition of marine geodiversity compartments; and (5) valuation of geodiversity and selection of key areas.

\subsection{Literature review and data acquisition}

Databases from government and research institutions as well as information available on the internet were consulted (see Supporting Information). The acquired data were derived from the main survey programs already carried out by the Brazilian Government in the Brazilian Legal Continental Shelf area over the last 40 years; these programs included REMAC (Reconhecimento Global da Margem Continental Brasileira [Global Recognition of Brazilian Continental Margin]), LEPLAC (Plano de Levantamento da Plataforma Continental Brasileira [Surveying Plan of the Brazilian Continental Shelf]), and REMPLAC (Programa de Avaliação da Potencialidade Mineral da Plataforma Continental Jurídica Brasileira [Program for Evaluating the Mineral Potential of the Brazilian Legal Continental Shelf]). 


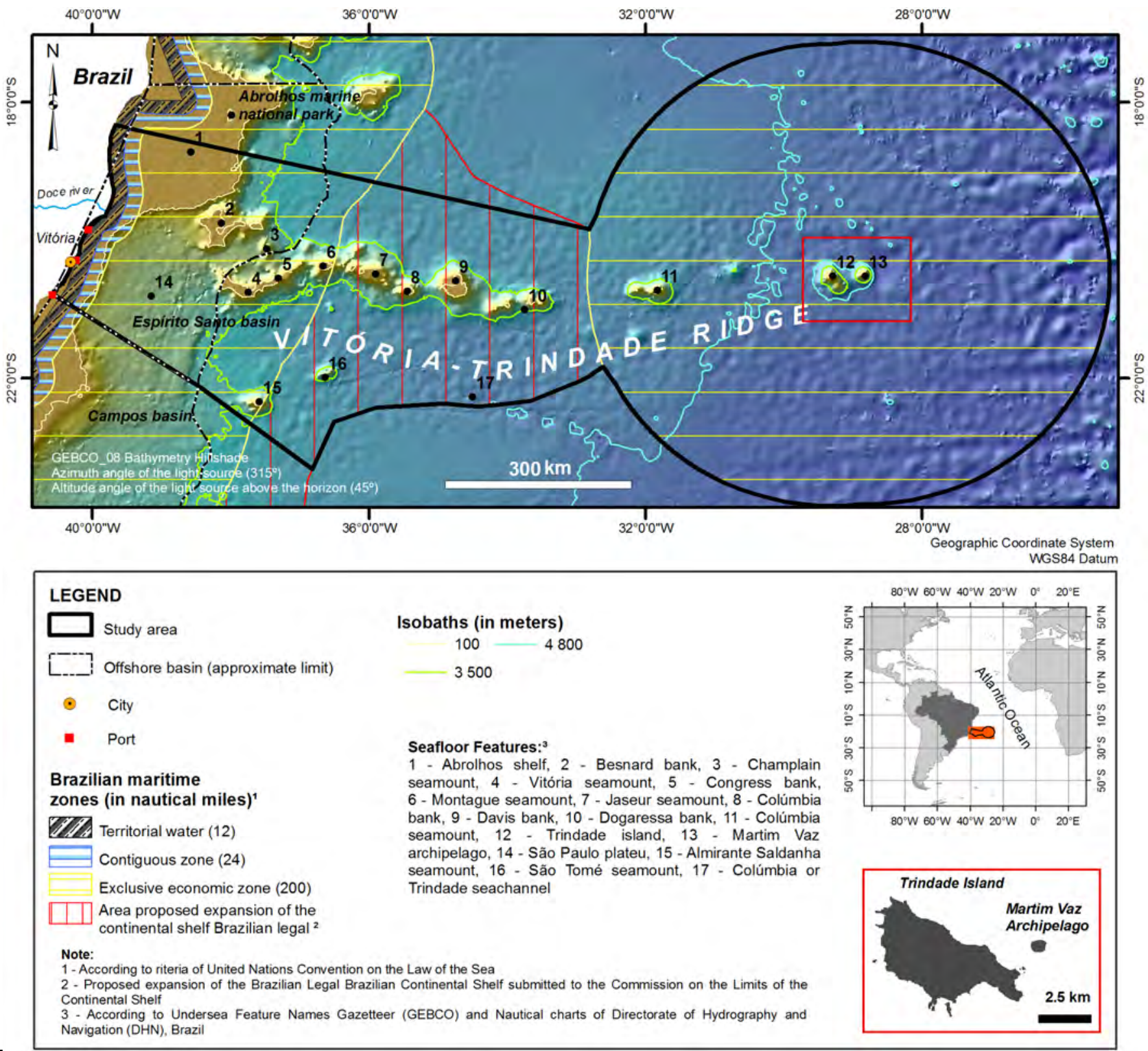

Figure 1 - Location of the study area. The names of locations are from Undersea Feature Names Gazetteer and Nautical Charts of the Directorate of Hydrography and Navigation (DHN), Brazil.

Figura 1 - Localização da área de estudo. Topônimos retirados das Cartas náuticas da Diretoria de Hidrologia e Nave$\operatorname{gação~}(D H N)$.

\subsection{Organization of data in the GIS}

Since data from various sources and corresponding to different acquisition dates, formats, scales, and cartographic projections were used, systematization of data procedures became necessary for the subsequent organization of the information in the GIS. The GIS organization and other functions were performed using ESRI ArcDesktop GIS (ArcMap, ArcScene, 3D Analyst Tools, Data Management Tools, Spatial Analyst) and Global Mapper (Version 12) programs.

The map projection used was the Geographic Coordinate Projections System and Universal Transverse Mercator (World Geodesic System 1984-WGS84 datum), which has a central meridian with a source latitude of $0^{\circ}$ and a source longitude origin of $33^{\circ} \mathrm{W}$ corresponding to Greenwich. The 1:2,500,000 scale was chosen for data integration since it allows for the analysis of the information within the GEBCO 08 data spatial resolution (see Supporting Information).

\subsection{Generation of products and auxiliary analyses}

In the GIS environment, geoprocessing techniques were applied and spatial data analysis was performed (e.g., information overlays, classifications, topological research, data interpolations via ArcGIS/Spatial Analyst Tools) on the acquired information to generate auxiliary 
a) Biographic consulting

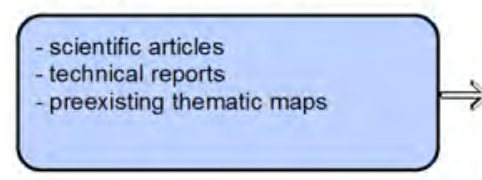

e) Definition of marine geodiversity compartments

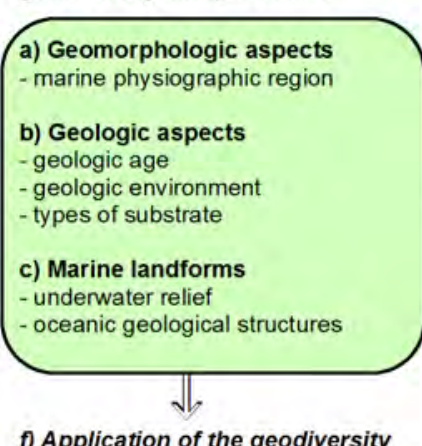

f) Application of the geodiversity values concept

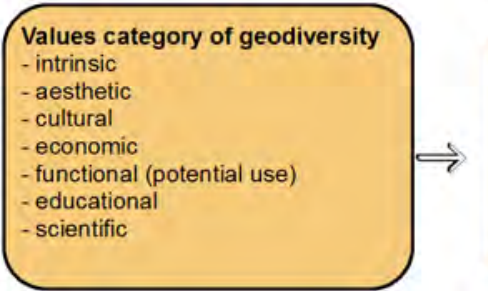

b) General data acquisition

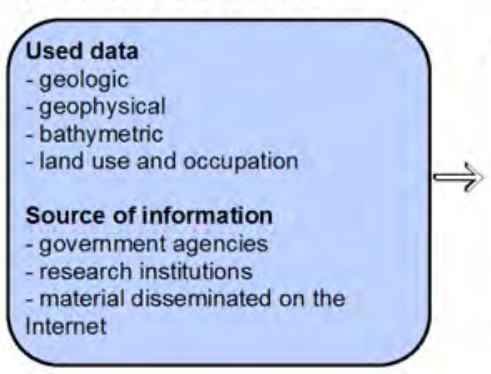

c) Organization of data in the GIS

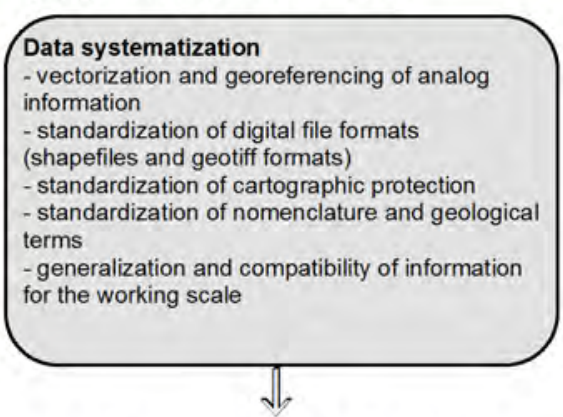

d) Generation of products and auxiliary analyses

\begin{tabular}{|c|c|c|}
\hline $\begin{array}{l}\text { Bathymetric data: } \\
\text { Numerical Terrain Model } \\
\text { (NTM } \\
\text { - bathymetric map } \\
\text { - isobate extraction } \\
\text { - hillshade } \\
\text { - declivity } \\
\text { - automatic extraction of } \\
\text { underwater channels } \\
\text { - bathymetric profiles } \\
\text { - colour shaded relif images } \\
\text { - 3D viewer }\end{array}$ & $\begin{array}{l}\text { Seabed sampling data: } \\
\text { Composition and distribution } \\
\text { pattern of sediments and } \\
\text { outcropping seabed } \\
\text { materials } \\
\text { - analysis of surface sediments } \\
\text { sampling, descriptions of rocky } \\
\text { materials, and seabed } \\
\text { sampling } \\
\text { - surface sediments samples } \\
\text { reclassification based on } \\
\text { texture, calcium carbonate }\end{array}$ & $\begin{array}{l}\text { content, and depth } \\
\text { Geophysical data: } \\
\text { Identification of marine } \\
\text { landforms and marine } \\
\text { geological structures } \\
\text { - feature identification and } \\
\text { geological structures in } \\
\text { seismic profiles } \\
\text { - identification of regional } \\
\text { tectonic framework }\end{array}$ \\
\hline
\end{tabular}

\section{g) Key areas representing marine}

geodiversity: Geoheritage and potential use

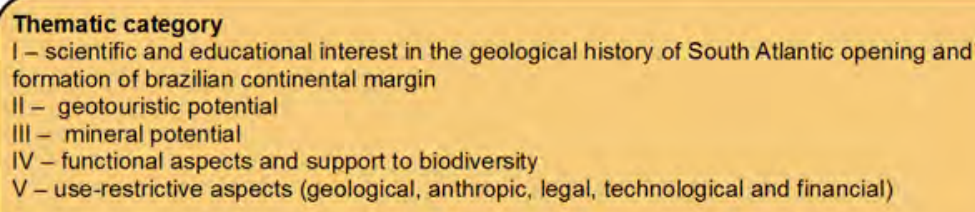

Figure 2 - Methodological procedure adopted in drawing up the sea geodiversity characterization model of the study area. Procedure stages: 1) bibliographic consultation and data acquisition (blue); 2) data organization in the geographic information system (GIS) (gray); 3) generation of products and auxiliary analyses (yellow); 4) definition of sea geodiversity compartments (green); and 5) valuation of geodiversity and selection of key areas (brown).

Figura 2 - Procedimento metodológico adotados na elaboração do modelo para caracterização da geodiversidade marinha da área de estudo. Etapas do procedimento: 1) consulta bibliográfica e aquisição de dados (azul); 2) organização dos dados em SIG (cinza); 3) geração de produtos e análises auxiliares (amarelo); 4) definição dos compartimentos da geodiversidade marinha (verde); e 5) valoração da geodiversidade e seleção das áreas-chaves (sépia).

thematic products that could be used to define geodiversity compartments such as those shown in Figure 2d):

Numerical Terrain Model (NTM): Obtained from the continuous surfaces of interpolated depth data from the GEBCO_08 Atlas. This model made it possible to obtain observations of seabed topography and other relief features associated with it.

The composition and distribution pattern of sediments and outcropping seabed materials: Owing to the absence of a regular sampling grid covering the entire area of study, a decision was made not to use traditional statistical analysis techniques for charac- terizing sedimentary deposits (e.g., measures of central tendency, measures of dispersion). However, analyses of the relationships between the characteristics of the elements on the seabed (composition and granulometry) and the sampling depths allowed us to establish meaningful information regarding the distribution pattern of surface sedimentary deposits.

Identification of marine landforms and marine geological structures: These landforms and structures were identified through bibliographic consultation and interpretative analyses of NTM products and available seismic profiles. 


\subsection{Definition of marine geodiversity compartments}

Geodiversity compartments were used in this study to identify the geological environments and landscapes that constitute marine surfaces resulting from geological and geomorphological processes.

The compartments of marine geodiversity were defined according to geomorphological aspects (positioning in relation to marine physiographic region), geological (geologic age, geological environment and type of substrate) and marine landforms (underwater relief and oceanic geological structures). Criteria and parameters are shown in Table 1.

The physiographic regions were defined based on the physiographic provinces proposed by França (1979) and Palma et al. (2008) for the Brazilian Atlantic mar- gin. The regions were delimited through geomorphological interpretation techniques based on the analysis of visual morphology (shape, texture, and roughness) and morphometric (depth, slope, and amplitude) aspects through NTM data. Note that such limits reflect exclusively the geomorphological features of the terrain and may not match the legal limits established by the United Nations Convention on the Law of the Sea UNCLOS.

\subsection{Valuation of geodiversity and selection of key areas}

According to Brilha (2005), geoheritage is related to geodiversity elements (minerals, rocks, soils, fossils, and geoforms) and outcropping resulting from either natural geodiversity processes or human intervention.

Table 1 - Features and parameters used to define marine geodiversity compartments in the study area.

Tabela 1 - Características e parâmetros utilizados na definição dos compartimentos da geodiversidade marinha da área de estudo.

\begin{tabular}{|c|c|c|c|c|}
\hline $\begin{array}{l}\text { GEOMORPHOLOGICAL AS- } \\
\text { PECTS }\end{array}$ & \multicolumn{3}{|c|}{ GEOLOGICAL ASPECTS } & $\begin{array}{l}\text { MARINE LAND- } \\
\text { FORMS }\end{array}$ \\
\hline Marine Physiographic Region & $\begin{array}{c}\text { Geologic } \\
\text { Age }\end{array}$ & $\begin{array}{l}\text { Geological Envi- } \\
\text { ronment }\end{array}$ & Types of Substrate & $\begin{array}{c}\text { Underwater relief and } \\
\text { Oceanic Geological } \\
\text { Structures }\end{array}$ \\
\hline $\begin{array}{l}\text { Continental Shelf of Espírito } \\
\text { Santo } \\
\text { - Depth between } 60 \text { and } 80 \mathrm{~m} \\
\text { - Flat surface with mild slopes } \\
\left(<0.3^{\circ}\right) \\
\text { Continental Slope of Espírito } \\
\text { Santo } \\
\text { - Depth between } 60-80 \text { and } \\
3,200 \mathrm{~m} \\
\text { - Uneven surface with mild to } \\
\text { moderate slopes }\left(3^{\circ} \text { to } 25^{\circ}\right) \\
\text { Continental Rise of Espírito } \\
\text { Santo } \\
\text { - Depth: } 3,200 \text { to } 4,800 \mathrm{~m} \\
\text { - Uneven surface with smooth to } \\
\text { steep slopes }\left(2^{\circ} \text { to } 14^{\circ}\right) \text {. Locally } \\
\text { upgraded forms of steep slopes. } \\
\text { Brazilian Abyssal Plain } \\
\text { - Depth: } 4,800 \text { to } 5,300 \mathrm{~m} \\
\text { - Flat surfaces with mild slopes } \\
\left(0.2^{\circ} \text { to } 5^{\circ}\right) \text {. Locally upgraded } \\
\text { forms of moderate to steep } \\
\text { slopes. }\end{array}$ & $\begin{array}{l}\text { Mesozoic } \\
(252 \text { to } \\
66 \text { million } \\
\text { years ago) }\end{array}$ & $\begin{array}{l}\text { Volcanic/Magmatic } \\
\text { - Eruptions and } \\
\text { strokes associated } \\
\text { with submarine vol- } \\
\text { canoes } \\
\text { - Volcanic strokes } \\
\text { associated with the } \\
\text { magma ascent zone } \\
\text { of the mid-oceanic } \\
\text { ridge }\end{array}$ & $\begin{array}{l}\text { Detritus } \\
\text { - Gravitational flow } \\
\text { deposits and mass } \\
\text { movement } \\
\text { - Turbidity deposits } \\
\text { and other bottom } \\
\text { currents }\end{array}$ & $\begin{array}{l}\text { Erosive/Depositional } \\
\text { - Buried channel (pa- } \\
\text { leochannel) } \\
\text { - Submarine bank } \\
\text { - Canyons and incision } \\
\text { - Fans and turbidite } \\
\text { channel } \\
\text { - Plateau } \\
\text { - Abyssal plains } \\
\text { Volcanic } \\
\text { - Volcanic buildings }\end{array}$ \\
\hline
\end{tabular}


The geoheritage is assigned as an individual criterion that is distinctly different from scientific, pedagogical, cultural, touristic, and other points of view. In this work, a descriptive approach was adopted to study the values and uses of marine geodiversity because of the need to raise intensive queries regarding the inventory and quantification of geoheritage mainly in the oceanic region.

The geoheritage of key areas representing the relevant aspects of the geodiversity in the Vitória - Trindade Ridge and adjacent areas was nominated based on the concept of geodiversity values established in studies conducted in continental environments, and these were adapted in the present study for application in the marine domain as the following categories: intrinsic, aesthetic, cultural, economic, functional (potential use), educational, and scientific (Gray, 2004; Brilha, 2005). The adjustment was made based on the geological context and the potential and restrictive aspects of use. The geological context was obtained through bibliographic analysis and data reinterpretation collected during the data acquisition phase.

The categories of values adopted in this study cover aspects related to the following themes:

(1) Scientific and educational interest in the geological history of the opening of the South Atlantic and formation of the brazilian continental margin - Examples Cenozoic geological history associated with variation in sea level during the Quaternary Period; Examples of mesozoic-cenozoic geological history associated with the Brazilian marginal sedimentary basins; Examples cof enozoic geological history associated with tectonomagmatic events on the Atlantic ocean; Examples of mesozoic-cenozoic geological history associated with the opening of the South Atlantic Ocean

(2) Geotouristic potential - Geological heritage registered by Brazilian body (SIGEP)

(3) Mineral potential - Deposits and mineral occurrences

(4) Functional aspects and support of biodiversity Peculiar ecosystems

(5) Use-restrictive - geological (Hazard), anthropic (environmental degradation from infrastructure installation and predatory extraction), legal (protected areas and other areas subject to specific legislation), and technological and financial.

\section{Results}

The geodiversity of the Vitória - Trindade Ridge and marine adjacent areas is a result of the interaction of tectonic, volcanogenic, and sedimentary Mesozoic and Cenozoic events and reworkings by marine geomor- phological processes conditioned mainly by eustatic sea level variations during the Quaternary period. Such events and processes are responsible for the great diversity of marine landscapes that depict the geological history of the planet related to seafloor spreading, the opening of the Atlantic Ocean, and formation of the BCM since the separation of the South American and African plates, which has been occurring from the Cretaceous period up to the present day.

The topography of the seabed in the study area is irregular, with depths ranging between 0 and $6,272 \mathrm{~m}$ below sea level, and several elevations can be observed at the seabed. Depths between 4,100 and 5,800 $\mathrm{m}$ are predominant; in the depth range of 3,500 and $4,800 \mathrm{~m}$, a set of isobaths projected towards the African continent occurs for about $980 \mathrm{~km}$, which corresponds to the Vitória - Trindade Ridge base and other underwater elevations.

From the physiographic point of view, the following marine regions can be identified from the coastline towards the offshore region (see Supporting Information):

\section{Continental shelf of Espirito Santo (CSES)}

The shelf extends for 30 to $210 \mathrm{~km}$ from the current coastline towards the open sea to the shelf break, and this region ranges in depth from 60 to $80 \mathrm{~m}$. It features a flat surface with soft slopes that are marked by topographic gaps between 10 and $20 \mathrm{~m}$. The main feature of this compartment is the significant enlargement of the shelf to the north, which corresponds to the southern portion of the Abrolhos Bank. According to Almeida (2000), this enlargement was caused by intense Cenozoic volcanic manifestations associated with the contributions of river deposits in the north-central portion of the area. From the $30 \mathrm{~m}$ isobaths, in the NTM products, linear subvertical structures with varied widths are observed, which are interpreted as paleochannels. Such structures extend across the entire CSES towards the CSLES (see below).

\section{Continental slope of Espírito Santo (CSLES)}

The slope comprises a narrow area less than $30 \mathrm{~km}$ wide and delimited at the $3,200 \mathrm{~m}$ isobath. It comprises wavy to heavily wavy surfaces with mild to moderate slopes. The slope is interrupted by submarine ravines and canyons associated with the effects of bottom currents.

\section{Continental rise of Espírito Santo (CRES)}

The rise represents the most extensive physiographic domain of the study area, and it extends for about 1,000 $\mathrm{km}$ to the $4,800 \mathrm{~m}$ isobath. The rise presents a great diversity of forms from extensive flat surfaces to deformed areas in the shape of domes and basins formed by the movement of evaporite deposits (São Paulo Plateau) and by volcanic mounts (Vitória - Trindade Ridge submerged portion) and other isolated seamounts. 


\section{Brazilian abyssal plain (BAP)}

The plain extends for 200 and $400 \mathrm{~km}$ to the $5,300 \mathrm{~m}$ isobath. It features a plane surface controlled by seafloor topography and structures occur in uplifted areas constituting abyssal hills. The Vitória - Trindade Ridge land portion is also present here.

\section{South Atlantic mid-oceanic ridge (SAMOR)}

The ridge occurs in the study area for about $200 \mathrm{~km}$ from the $5,300 \mathrm{~m}$ isobath, which corresponds to the western flank of the ridge. The landforms present solid structural control and form valleys and ridge crests associated with fracture zones, with average amplitude of $250 \mathrm{~m}$.

The surface of the seabed is composed of shallow water marine sedimentary deposits of ultra-deep deposits formed during Cenozoic events and rocks from Cenozoic volcanomagmatic events. Cenozoic deposits cover the oldest sedimentary rocks and Mesozoic-Cenozoic volcanic rocks in the Espírito Santo and Campos Basins and the oceanic crust, whose age varies from 65 to 134 million years (Maia, 2013). The total thickness of this sedimentary sequence ranges from 500 to $5,500 \mathrm{~m}$, with the thinnest rocks located south of the Vitória - Trindade Ridge in the BAP region and along the western flank of the SAMOR, while the thickest occur in the region corresponding to the Espírito Santo Basin.

\subsection{Marine geodiversity compartments of the Vitó- ria - Trindade Volcanic Seamount Ridge and ma- rine adjacent areas: key areas and potential use}

Based on the adopted methodological procedures, were identified 5 compartments of geodiversity and its subdivisions (Table 2), described according to the geological characteristics of outcropping materials at the ocean floor, submerged landforms and oceanic geological structures in the area.

Relevant aspects were selected through key areas, as described below, in terms of geoheritage and potential uses (Figure 3).

Table 2 - Corresponding to the area of marine geodiversity compartments mapped in the study area (Total Area: $\left.739,226.977 \mathrm{~km}^{2}\right)$.

Tabela 2 - Área correspondente aos compartimentos da geodiversidade marinha mapeados na área de estudo (Área Total: $\left.739,226.977 \mathrm{~km}^{2}\right)$.

\begin{tabular}{|c|c|c|}
\hline \multicolumn{2}{|c|}{ Geodiversity Compartments } & Area $\left(\mathbf{k m}^{2}\right)$ \\
\hline \multirow{3}{*}{$\begin{array}{l}\text { 1. Cenozoic marine deposits from } \\
\text { shallow waters in the continental } \\
\text { shelf of the Espírito Santo and } \\
\text { oceanic submarine banks }\end{array}$} & 1.1. Modern bioconstruction & $\begin{array}{c}14,849.882-2.008 \% \\
\text { (continental shelf: } 9,295.458-1.257 \% \\
\text { oceanic submarine banks: } 5,554.424-0.751 \text { ) }\end{array}$ \\
\hline & 1.3. Terrigenous deposits & $1,976.483-0.267 \%$ \\
\hline & 1.4. Bioclastic deposits & $16,667.956-2.254 \%$ \\
\hline $\begin{array}{l}\text { 2. Cenozoic marine deposits from } \\
\text { shallow to deep water in the con- } \\
\text { tinental slope of the Espírito } \\
\text { Santo }\end{array}$ & $\begin{array}{l}\text { 2.1. Deposits from debris flow and subma- } \\
\text { rine mass movements }\end{array}$ & $4,222.437-0.571 \%$ \\
\hline \multirow{4}{*}{$\begin{array}{l}\text { 3. Mesozoic-Cenozoic marine de- } \\
\text { posits from deep to ultra-deep } \\
\text { water in the Continental rise of } \\
\text { Espírito Santo }\end{array}$} & 3.1. Pelagic and fine terrigenous deposits & $219,905.883-29.748 \%$ \\
\hline & $\begin{array}{l}\text { 3.2. Tubiditic channel and submarine fans } \\
\text { deposits }\end{array}$ & $34,912.258-4.722 \%$ \\
\hline & 3.3. Authigenic deposits (evaporite) & $1,550.516-0.209 \%$ \\
\hline & $\begin{array}{l}\text { 3.4. Authigenic deposits (polymetallic nod- } \\
\text { ules and crusts) }\end{array}$ & $2,227.010-0.301 \%$ \\
\hline \multirow[t]{3}{*}{$\begin{array}{l}\text { 4. Cenozoic volcanism in the con- } \\
\text { tinental rise of the Espírito Santo } \\
\text { and Brazil abyssal plain }\end{array}$} & $\begin{array}{l}\text { 4.1. Lavas and sodium-alkaline intrusions, } \\
\text { and sedimentary deposits of the emerged por- } \\
\text { tion of the Vitória - Trindade Ridge (Trin- } \\
\text { dade Island and Martim Vaz Archipelag) }\end{array}$ & $13.005-<0.0001 \%$ \\
\hline & $\begin{array}{l}\text { 4.2. Ultrabasic-alkaline volcanic intrusions in } \\
\text { the submerged portion of Vitória - Trindade } \\
\text { Ridge }\end{array}$ & $5,9247.306-8.014 \%$ \\
\hline & 4.3. Volcanic intrusions of unknown genesis & $3,846.283-0.520 \%$ \\
\hline $\begin{array}{l}\text { 5. Mesozoic-Cenozoic marine de- } \\
\text { posits from ultra-deep waters } \\
\text { and volcanism in the Brazil } \\
\text { abyssal plain and South atlantic } \\
\text { mid-oceanic ridge }\end{array}$ & $\begin{array}{l}\text { 5.1. Pelagic deposits associated with basaltic } \\
\text { rocks }\end{array}$ & $379,807.958-51.378$ \\
\hline
\end{tabular}




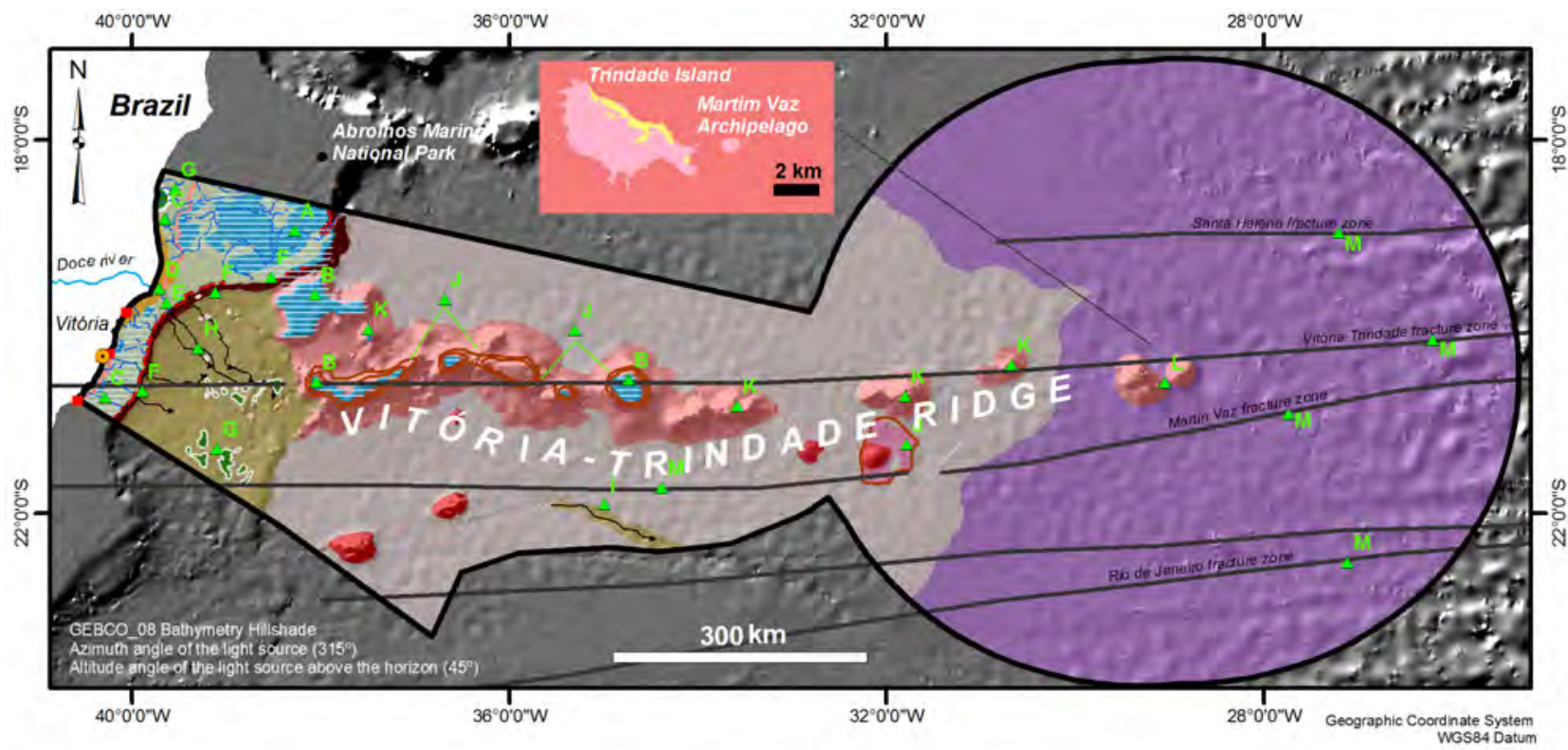

Legend

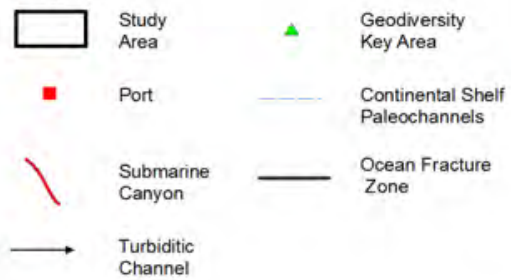

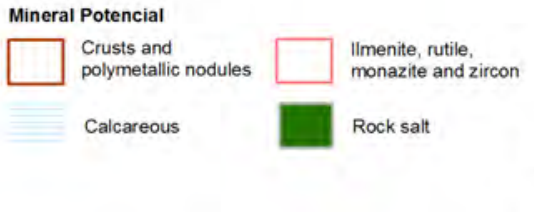

Seafloor Features:

1 - Abrolhos shelf, 2 - Besnard bank, 3 Champlain seamount, 4 - Vitória seamount, 5 - Congress bank, 4 -Vitoria de - Congress 7 -Montague ceamount, 8 Columbia bank, 9 - Davis bank, 10 Dogaressa bank, 11 - Colúmbia seamount. 12 - Trindade island, 13 - Martim Vaz archipelago, 14 - São Paulo plateu, 15 Almirante Saldanha seamount, 16 - São Tomé seamount, 17 - Colúmbia or Trindade seachannel

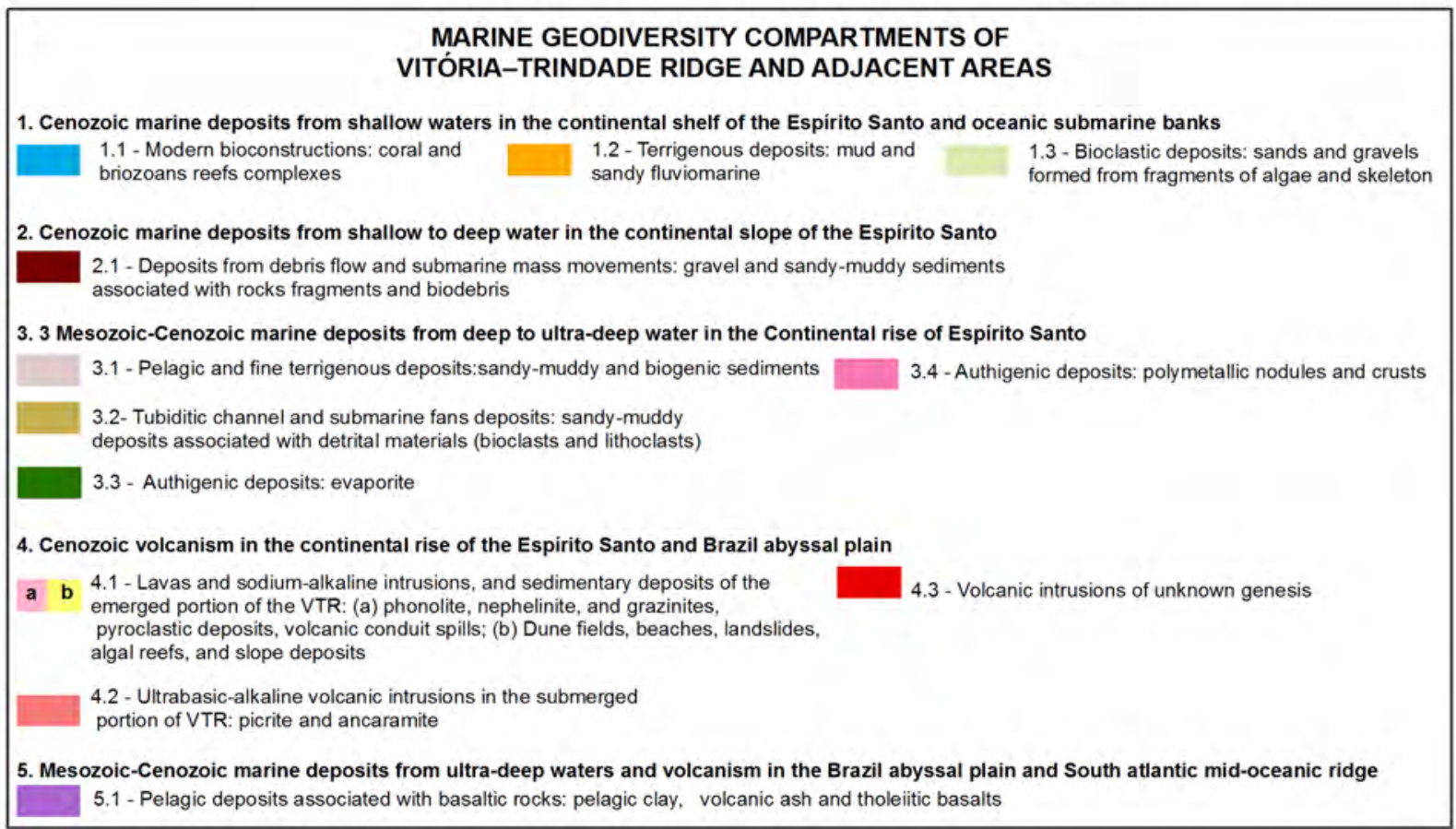

\begin{tabular}{|c|c|}
\hline \multicolumn{2}{|c|}{$\begin{array}{l}\text { MARINE GEODIVERSITY: KEY AREAS OF } \\
\text { VITÓRIA-TRINDADE RIDGE AND ADJACENT AREAS }\end{array}$} \\
\hline $\begin{array}{l}\text { A- Reefs in the southern portion of Abrolhos Bank } \\
\text { B- Reefs above oceanic submarine banks } \\
\text { C. Marine granular deposits } \\
\text { D. Submerged portion of Doce River Delta } \\
\text { E- Continental shelf paleochannels } \\
\text { F. Systems of canyons and submarine incisions in the slope edge } \\
\text { G- Evaporite Deposits }\end{array}$ & $\begin{array}{l}\text { H- Systems of turbidites and submarine fans in the São Paulo Plateau } \\
\text { 1. Columbia seachannel } \\
\text { J-Polymetallic deposits } \\
\text { K- Seamounts and submarine volcanic banks of the Vitória-Trindade Ridge } \\
\text { L-Trindade Island and the Martim Vaz Archipelago } \\
\text { M- Fracture zones of the western flank of the mid-ocean ridge in the South } \\
\text { Atlantic }\end{array}$ \\
\hline
\end{tabular}

Figure 3 - Marine geodiversity compartments of the Vitória-Trindade Ridge and adjacent areas.

Figura 3 - Compartimentos da geodiversidade marinha da Cadeia Vitória-Trindade e áreas 


\subsubsection{Cenozoic marine deposits from shallow waters in the continental shelf of the Espirito Santo and oceanic submarine banks}

This compartment corresponds to Cenozoic shallow waters deposits and marine landscapes formed in the CSES region and adjacent submarine Vitória - Trindade Ridge banks. The deposits were formed by bioconstructions e and fluvial discharge action, then reworked by wave action and tides along the Quaternary:

(1.1) Modern bioconstruction: corresponds to complexes of coral reefs and bryozoans consisting of a series of marine organisms with calcareous skeletons or algae that generally develop on the volcanic substratum. Calcareous algae, rodolites, and bryozoans occur, and these are associated with bioclastic sedimentation comprising sludge, sand, and biodetritic gravel, which contains fragments of corals, gastropods, and calcareous shells of bivalves;

(1.2) Terrigenous deposits: consist of continental sediments that have been deposited and reworked in the shallow marine environment. Mud associated with the outfall of the Doce River Delta and sandy fluviomarine sediments are present; and

(1.3) Bioclastic deposits: mostly composed of bioclastic sediments, with calcium carbonate levels greater than $70 \%$, and they are represented by sands and gravels formed from fragments of coralline algae, bryozoans, mollusks, and benthic foraminifera.

\section{Geodiversity relevant aspects:}

\section{Key area $A$ - Reefs in the southern portion of the Abrolhos Bank}

These reefs correspond to the southern portion of the most extensive reef complex in the South Atlantic Ocean (Leão, 2002); it is similar in area to the Great Barrier Reef in Australia. The Abrolhos Marine National Park is located about $200 \mathrm{~km}$ north of the study area; this park was classified by SIGEP as a geobiological site. It is comprised of sources of calcium carbonate and magnesium that are used as biofertilizers and are employed worldwide in agriculture and civil construction. Economic exploitation in this region is currently barred by Brazilian governmental bodies as a measure to protect the local ecosystem. These environments are sensitive to sea-level oscillations and thus constitute an important marker of the changes along the Brazilian coast, especially at the end of the Holocene during the last regressive phase (Leão, 2002). They are unique ecosystems from geomorphological and biological points of view and are important for maintaining marine biodiversity that can absorb carbonic gas diluted in the sea and turn it into limestone. They are directly influenced by the composition of bedrock and terrestrial sediment supply, and importantly, they represent one example of the functional relation between geodiversity and biodiversity.

\section{Key area B - Reefs above oceanic submarine banks}

Almeida (2002) describes the presence of coral reefs on the submerged tops of the Vitória - Trindade Ridge (Besnard Bank, Vitória Seamount, Montague Seamount, and Davis Bank), that were made plane by marine erosion during the phase where the exposure of the tops occurred when the sea level reached about 120 meters below current sea level at the last glacial period during the Quaternary. Between 2008 and 2011, calcareous algae in the region (Davis Bank) were exploited for use as agricultural inputs. An authorization for mine exploration estimated to have covered a region of around 150 thousand hectares was overturned by the Brazilian Government under the claim that the reservation was beyond the Brazilian EEZ and reached into international legal waters (Cavancanti, 2011).

\section{Key area C - Marine granular deposits}

According to Cavalcanti (2011), the Brazilian continental shelf represents the most extensive carbonate deposition environment in the world. In the study area, it is comprised of bioclastic deposits arising from the breakdown of shells of organisms and coral reefs spread all over the CSES. In terrain deposits, sands and quartzofeldspathic gravels are predominant, which are commonly associated with heavy minerals (ilmenite, rutile, monazite, and zircon); these deposits occur mainly near the mouth of the Doce River and near the southern coast of this region (Palma, 1979). They are used in civil construction and beach widening projects. The exploitation of such deposits depends on grants provided by environmental and regulatory agencies, which aim to protect the surrounding coral reefs among other important elements.

\section{Key area D - Submerged portion of the Doce River Delta}

There are several marine deltaic systems on the Brazilian coast; one of them is the Doce River Delta, the main delta in southeastern Brazil. Its submerged portion extends over an area of $200,000 \mathrm{~km}^{2}$. The Doce River Delta stands out as an unique coastal landscape, with a progradation zone associated with the outfall of the Doce River, whose evolution is related to variations in the sea level through the Quaternary (Sunguio et al., 1982). The delta is composed of landscapes peculiar to the transition region between the continental and marine geodiversity. Deltas influence the composition and distribution of sedimentary deposits, which work as barriers to the development of bioconstructions in the CSES.

\section{Key area E - Continental shelf paleochannels}

Quaternary changes in sea level resulted in the formation of channels (paleochannels) in the Brazilian shelf 
that were excavated during episodes of low sea level (Pleistocene) and buried by the Holocene sediments during episodes of sea level rise (França, 1979). The path of these channels suggests connectivity with the continental drainage system, with topographical expression up to the CSES edge, where they interconnect with the canyon systems of the continental slope (Maia, 2013). One of the most prominent channels, which stretches out to the continental slope, is located off the city of Vitória; it is named the Vitória Channel. Resources such as heavy minerals, diamonds, and gold associated with paleochannels are exploited economically in various parts of the world such as New Zealand, South Africa, and Japan (Cavalcanti, 2011). Palmas (1979) describes the occurrence of heavy minerals associated with paleochannels in the CSES, especially in the area of the Doce River Delta and in the southern portion of the study area. The exploitation of potential deposits in the area is subject to legal and environmental issues and factors such as financial and technological resources.

\subsubsection{Cenozoic marine deposits from shallow to deep water in the continental slope of the Espirito Santo}

This compartment corresponds to Cenozoic shallow, deep and ultra-deep waters deposits and marine landscapes located in CSLES. The deposits comprise sediments from the continental shelf transported by turbidity currents, chaotic deposits from gravitational flows (debris flows and turbidity currents), and depositional events of short duration (drops of rock, crawl, marine landslides, and collapses) from the slope itself: (2.1) Deposits from debris flow and submarine mass movements: The upper portion of these deposits is composed of sandy-muddy sediments containing gravel and biodebris associated with materials from the flow of mud and debris transported offshore. In the lower portion of the deposits, sandy-muddy sediments are predominant, with gravel and detrital material comprising bioclastic and coral fragments and material from the superficial portion of the sedimentary package.

\section{Geodiversity relevant aspects:}

\section{Key area $F$ - Systems of canyons and submarine inci- sions in the slope edge}

In general, the continental slope is disrupted by canyons and incision marine landforms, by which the sediments reach the deepest regions of the ocean. It constitutes regions of high susceptibility to the development of geological processes associated with submarine mass movement and flow of debris. Such processes take place, mainly, from a high gradient of chaotic sediment accumulation and the action of geotrophic currents along the submarine slope. Accordingly, care should be taken in this region while implementing infrastructure and developing exploitation activities connected to the oil industry. Some of these geomorphic features were described by Schreiner et al. (2009) and identified by Maia (2013) in the south-central portion of the study area through an analysis of bathymetric data; among these features, the Regência, Vitória, Rio Doce, and Watu Norte e Watu Sul canyons and Regência ravine system stand out.

\subsubsection{Mesozoic-Cenozoic marine deposits from deep to ultra-deep water in the Continental rise of Espírito Santo}

This compartment corresponds to deep and ultra-deep waters deposits and marine landscapes located in CRES. These deposits are resulted from several geological processes that occurred through the MesozoicCenozoic periods:

(3.1) Pelagic and fine terrigenous deposits: Pelagic deposition (carbonate vases) was predominant and it associated with deposits from continental sediment discharges by turbidite currents and authigenic processes. Represented by sandy-muddy and biogenic sediments that have been reworked by the bottom flow. Ash, volcanic fragments, palagonite (altered volcanic ash), manganese micronodes, magnetite, and mica are present. The coarse fractions contribute up to $10 \%$ of the total volume and comprise a wide variety of planktonic and benthic foraminifera. The bioelements include ooze, marl, foraminiferal sand, sponge spicules, echinoid shells, and fish teeth, which are associated with terrigenous sediments with predominant mica and fine quartz sand;

(3.2) Tubiditic channel and submarine fans deposits: deposits formed by turbidite flows through a system of channels and submarine fans. They occur in various regions of the continental rise, and particularly in the southwestern and southern regions of the Vitória Trindade Ridge. In general, they are characterized by sandy and sandy-muddy deposits associated with detrital materials (bioclasts and lithoclasts). The coarse fraction is composed of mainly planktonic foraminifera, pteropods, and gastropods. Mineral elements consist essentially of grains of quartz, mica, and heavy minerals. Hydrogen sulfide was detected in these sediments;

(3.3) Authigenic deposits (evaporite): occur in the form of small diapiric outcropping near the shoreline and form conspicuous salt domes (more than 5,000 m thick) at depths greater than $300 \mathrm{~m}$ (Mohriak, 2008); and

(3.4) Authigenic deposits (polymetallic nodules and crusts): polymetallic nodules and crusts (iron manganese) that are widely distributed on the seabed;

\section{Geodiversity relevant aspects:}

\section{Key area $G$ - Evaporite deposits}

The formation of Aptian evaporite deposits represents one of the major geological events that occurred during 
the Cenozoic in the sedimentary coastal basins of Brazil; these saline deposit movements have been reported to extend up to the recent period (Mohriak, 2008). In the Campos Basin, these deposits are associated with the discovery of oil fields known as pre-salt oil and gas fields. The displacement of evaporites led to intense structural deformation of the ocean floor and gave rise to geological domes and basins (synclines and anticlines) characteristic of the São Paulo Plateau area. They consist of rock salt associated with potassium, sulfur, sulfide, and vanadium, which is commonly used as an agricultural input. The deposits located in CSES, near the mouth of the Doce River, have been the subject of research and mining prospects. The exploitation of these rock salt deposits may decrease the dependence of Brazil on fertilizer imports.

\section{Key area $\boldsymbol{H}$ - Systems of turbidites and submarine fans in the São Paulo Plateau}

This represents one of the largest turbidite systems from the Brazilian shelf, and it is formed of extensive networks of meandering channels and turbidite fans on the irregular seabed in the northern segment of the São Paulo Plateau. The turbidite systems of the Doce River and Watu are examples of the central region in the study area (Schreiner et al., 2009). They constitute areas subject to intense sedimentary transport, where the main oil and gas exploration wells are located in the Espírito Santo and Campos Basins.

\section{Key area I - Columbia sea channel}

According to Faugères et al. (2000) and Motoki et al. (2012), the Columbia Channel may be the largest and main distal turbidite system that developed in the Paleocene along basement structural grabens; its formation was the result of actions by contour currents influenced by the Vitória - Trindade Ridge. In the study area, the portion of this channel that can be mapped is located south of the ridge, extending to the southeast; this region is approximately $150 \mathrm{~km}$ long, $20 \mathrm{~km}$ wide, and its thickness, though not determined yet, is speculated by authors to be about $1 \mathrm{~km}$.

\section{Key area J-Polymetallic deposits}

According to Palmas \& Pessanha (2000), climatic oscillations and the participation of benthic organisms in sediment changes leading to the formation of microenvironments represent important conditioning factors in the formation of these deposits. They occur in the form of polymetallic nodules of various compositions (manganese, copper, nickel, and cobalt) that cover the CRES seabed and form a polymetallic crust on top of the Vitória - Trindade Ridge seamounts (Palma, 1979). Cobalt-rich crustal materials and polymetallic nodules have been identified in the Vitória, Montague, Jaseur, and Davis Banks in the Vitória - Trindade Ridge
(CPRM, 2008); however, the technical and financial feasibility for extraction of these deposits needs to be verified through further study. In particular, thorough studies are necessary to detail economically viable deposits belonging to the Brazilian EEZ. Countries such as Japan, the United States, Russia, Germany, France, Korea, the United Kingdom, and China have shown interest in these deposits (Calvalcanti, 2011). Recently, Brazil received authorization from the International Seabed Authority (ISA), a United Nation's agency, to evaluate the economic potential of mafic cobalt-rich deposits in the Rio Grande Elevation, which is located about $1,000 \mathrm{~km}$ south of the study area.

\subsubsection{Cenozoic volcanism in the continental rise of the Espírito Santo and Brazil abyssal plain}

This compartment is composed of rocks and landscapes generated by tectonomagmatic activity giving rise to the Vitória - Trindade Ridge, during the Cenozoic along the CRES and BAP:

(4.1) Lavas and sodium-alkaline intrusions, and sedimentary deposits of the emerged portion of the Vitoria Trindade Ridge (Trindade Island and Martim Vaz Archipelag): The Trindade Island consists of sodiumalkaline volcanic rocks (phonolite, nephelinite, and grazinites), pyroclastic deposits, and volcanic conduit spills (Almeida, 2002). The Holocene stratigraphic units occupy a small area on the Trinidade Island (dune fields, beaches, landslides, algal reefs, and slope deposits) (Castro, 2010); geochemistry indicated bimodal magmatism with a strong $\mathrm{Pb}$ anomaly similar to that observed on the submerged portion of the Vitória Trindade Ridge (Hansen et al., 1998, cited in Almeida, 2002); dating carried out by Cordani (1970) revealed ages between 3.7 and $1.1+0.5 \mathrm{Ma}(\mathrm{K} / \mathrm{Ar})$. The Martim Vaz Archipelago consists of undersaturated alkaline volcanic rocks (ankaratrite, tambuschite, phonolite, and perquinite) (Castro \& Antonello, 2006);

(4.2) Ultrabasic-alkaline volcanic intrusions in the submerged portion of Vitória - Trindade Ridge: studies in the submerged portion of the ridge are scarce; samples dredged in the central portion of the Vitória-Trindade Ridge (Colúmbia Seamount, Jaseur Seamount, Dogaressa Bank, and Davis Bank) reveal rocks of ultrabasicalkaline composition (picrite and ancaramite). Dating of the rocks in the upper portion of the volcanic sequence suggests a U-Pb age of $29.8 \pm 6.6 \mathrm{Ma}$ (Fodor \& Hanan, 2000; Skolotnev et al., 2011). In bottom dredging in Davis and Dogaressa banks revealed the presence of carbonate formations that have been dated Miocene (19-24 Ma) (Skolotnev et al., 2011); and

(4.3) Volcanic intrusions of unknown genesis: corresponds to intrusions into the seabed, the composition and age are indeterminate due to the absence studies. 


\section{Geodiversity relevant aspects:}

Key area $K$-Seamounts and submarine volcanic banks of the Vitória-Trindade Ridge

This region plays an important role in providing environmental services and support to the biodiversity of the South Atlantic. It constitutes a physiographic barrier that diverts Brazil's maritime flow and favors the emergence of important resurgence areas in coastal southeastern Brazil (Silveira et al., 2000). According to Gasparini \& Floeter (2001), the proximity between the top of the elevations (about $25 \mathrm{~km}$ distance between them) and the shallow deposits (less than $150 \mathrm{~m}$ ) makes Vitória - Trindade Ridge a "springboard" for coastal species to reach oceanic areas far from the coast, thus leading to economically exploited fishing. The use of volcanic rocks rich in potassium silicate as fertilizers through a powdered rock technique is an active area of research in Brazil. Thus, resources from volcanic seamounts may have potential for application in agriculture in the future. However, owing to mining in the oceanic areas, the legal, environmental, technological, and economic aspects of these deposits have to be further evaluated. Motoky et al. (2012) describe the occurrence of landslides along the slopes of these volcanic seamounts.

\section{Key area L-Trindade Island and the Martim Vaz Ar- chipelago}

Trindade Island was discovered in 1501 by Portuguese navigators and was recognized by the Brazilian Commission of Geological and Paleontological Sites as a marine geoheritage site. It is considered the most recent volcanic manifestation above the sea in the South Atlantic. According to Almeida (2002), it represents an area of relevant interest for researches on the origin and differentiation of magmas in the oceanic crust. On Trindade Island, preserved volcanic structures that are rare in Brazilian territory (necks, radial dikes, and ash cones) can be observed along with extremely undersaturated alkaline associations representing various stages of magmatic differentiation and scenic beauties (beaches, reefs, dunes, peaks, incised valleys, plateaus, and erosive processes) (Castro, 2010; Pires et al., 2013). Trindade Island and Martin Vaz Archipelago do not have touristic infrastructure, and Trindade Island is currently occupied by the Brazilian Navy, which has an observation post for national security purposes and to support scientific research. The Oceanic Islands constitute a special ecosystem of rich biodiversity resulting from the geographic isolation, and this provides suitable conditions for the existence of endemic species. As a result of the occupation by Azorean settlers on Trindade Island in the 18th century, herds of domestic animals were introduced, and these along with coastal systems processes caused erosion on the slopes and the development of gullies and landslides (Castro \& Antonello, 2006).

\subsubsection{Mesozoic-Cenozoic marine deposits from ultra- deep waters and volcanism in the Brazil abyssal plain and South atlantic mid-oceanic ridge}

This compartment corresponds to Mesozoic volcanic rocks associated with Cenozoic marine deposits from ultra-deep waters and marine landscapes located in SAMOR. During ocean floor expansion through the SAMOR, extravasation of tholeiitic basalts known as mid-oceanic ridge basalts or MORB, which are responsible for the formation of the oceanic crust, occurred. The deposition of pelagic and volcanoclastic sediments was associated with basalts that formed the new oceanic crust:

(5.1) Pelagic deposits associated with basaltic rocks: consist of calcareous slate and clay turbidites reworked by an underflow on older sedimentation and even the outcropping of rocks from the oceanic crust, which are represented by tholeiitic basalts. The deposits consist of yellowish-brown pelagic clay, which is suggestive of slow deposition conditions, along with stains, manganese nodules, volcanic ash, mica, manganese lenses, and occasionally, quartzose fine sand. The carbonate content is low or absent $(<2 \%)$. In the coarse fraction, manganese nodules and palagonite are common. Eventually, quartz granules, mica, and more rarely, fragments of sedimentary rocks are observed. Bioelements include fish teeth, sponge spicule fragments, echinoid spicules, planktonic foraminifera, diatoms, and radiolarians.

\section{Geodiversity relevant aspects:}

Key area M-Fracture zones of the western flank of the mid-ocean ridge in the South Atlantic

They represent features extending in an approximately $\mathrm{W}-\mathrm{E}$ direction and are diagonal to the SAMOR accretion area of the oceanic crust. Such structures are associated with the rupture and separation of the South American and African lithosphere plates, which occurred in the Mesozoic (Almeida, 2002).

Fracture zones are represented on the surface as crests and structural valleys (inactive fracture zones), as seen in the continental portion in the form of the Alto do Vitória that separates the sedimentary basins of Campos and Espí-rito Santo (Alves et al., 2006; Schreiner et al., 2009).

This region represents one of the few areas in Brazil under the SAMOR physiographic domain, and it is classified in the literature as the Santa Helena, Martin Vaz, Rio de Janeiro, and Vitória-Trindade fracture zones in the Vitória - Trindade Ridge (CPRM, 2008). The geological environment is favorable to the formation of polymetallic sulfide deposits related to hydrothermal vents. It is located in ultra-deep waters, and mineral exploitation would depend on financial and technological resources. 
Table 3 summarizes the geoheritage and aspects of use of the key areas that represent relevant Vitória - Trindade Ridge geodiversity compartments and marine adjacent areas.

\section{Discussion and final considerations}

This study proposes a regional-scale model to characterize marine geodiversity on the seabed. The model was based on information available in literature and on the reinterpretation of bathymetric, geological, and geophysical data. Such an approach was adopted mainly because of the lack of systematized information on this type of physical medium, and it was adapted directly to geodiversity characterization procedures. The application of this model to the Vitória - Trindade Ridge and adjacent areas has proved satisfactory for the macroscale characterization of the diversity of the geological features and marine landforms.

The Vitória - Trindade Ridge and adjacent areas display unique aspects of marine geodiversity that are of national and international importance. These features are related to the evolutionary processes of the South

Table 3 - Geoheritage and aspects of use of the key areas representing the geodiversity of the Vitória-Trindade Ridge and adjacent areas.

Tabela 3 - Patrimônio geológico e aspectos de uso das áreas-chaves representativas da geodiversidade da Cadeia VitóriaTrindade e áreas adjacentes.

\begin{tabular}{|c|c|c|}
\hline $\begin{array}{c}\text { Thematic Category of Geodiver- } \\
\text { sity Values }\end{array}$ & Geoheritage and Potential Use & Marine Geodiversity: Key Areas \\
\hline \multirow{4}{*}{$\begin{array}{l}\text { I - Scientific and educational inter- } \\
\text { est in the geological history of the } \\
\text { opening of the South Atlantic and } \\
\text { formation of the brazilian continen- } \\
\text { tal margin }\end{array}$} & $\begin{array}{l}\text { Examples cenozoic geological history associ- } \\
\text { ated with variation in sea level during the Quater- } \\
\text { nary Period }\end{array}$ & $\mathrm{A}, \mathrm{B}, \mathrm{D}, \mathrm{E}, \mathrm{F}, \mathrm{H}$ \\
\hline & $\begin{array}{l}\text { - Examples of mesozoic-cenozoic geological his- } \\
\text { tory associated with the Brazilian marginal sedi- } \\
\text { mentary basins }\end{array}$ & $\mathrm{A}, \mathrm{B}, \mathrm{D}, \mathrm{E}, \mathrm{F}, \mathrm{G}, \mathrm{H}$ \\
\hline & $\begin{array}{l}\text { Examples cof enozoic geological history asso- } \\
\text { ciated with tectonomagmatic events on the Atlan- } \\
\text { tic ocean }\end{array}$ & $K, L$ \\
\hline & $\begin{array}{l}\text { Examples of mesozoic-cenozoic geological } \\
\text { history associated with the opening of the South } \\
\text { Atlantic Ocean }\end{array}$ & $\mathrm{G}, M$ \\
\hline \multirow[t]{2}{*}{ II - Geotouristic potential } & $\begin{array}{l}\text { - Geological heritage registered by Brazilian } \\
\text { body (SIGEP) }\end{array}$ & A, $L$ \\
\hline & - Special marine landform & $\mathrm{A}, \mathrm{B}, \mathrm{D}, \mathrm{E}, \mathrm{F}, \mathrm{G}, \mathrm{H}, \mathrm{I}, K, L$ \\
\hline III - Mineral potential & - Deposits and mineral occurrences & $\mathrm{A}, \mathrm{B}, \mathrm{C}, \mathrm{E}, \mathrm{F}, \mathrm{G}, \mathrm{J}, K$ \\
\hline $\begin{array}{l}\text { IV - Functional aspects and sup- } \\
\text { port of biodiversity }\end{array}$ & - Peculiar ecosystems & $\mathrm{A}, \mathrm{B}, \mathrm{D}, K, L$ \\
\hline \multirow{4}{*}{$\mathrm{V}$ - Use-restrictive aspects } & - Geological: Hazard & $\mathrm{F}, \mathrm{G}, \mathrm{H}, K, L$ \\
\hline & $\begin{array}{l}\text { - Anthropic: environmental degradation from } \\
\text { infrastructure installation and predatory extraction }\end{array}$ & A, \\
\hline & $\begin{array}{l}\text { - Legal: protected areas and other areas subject } \\
\text { to specific legislation }\end{array}$ & $\mathrm{A}, \mathrm{B}, \mathrm{C}, \mathrm{D}, \mathrm{E}, \mathrm{G}, \mathrm{J}, K$ \\
\hline & - Technological and financial & $\mathrm{B}, \mathrm{C}, \mathrm{D}, \mathrm{E}, \mathrm{G}, \mathrm{J}, K$ \\
\hline
\end{tabular}

Note: A - Reefs in the southern portion of Abrolhos Bank, B - Reefs above oceanic submarine banks, C - Marine granular deposits, D Submerged portion of Doce River Delta, E - Continental shelf paleochannels, F - Systems of canyons and submarine incisions in the slope edge, G - Evaporite Deposits, H - Systems of turbidites and submarine fans in the São Paulo Plateau, I - Columbia seachannel, J - Polymetallic deposits, K - Seamounts and submarine volcanic banks of the Vitória-Trindade Ridge, L - Trindade Island and the Martim Vaz Archipelago, and M - Fracture zones of the western flank of the mid-ocean ridge in the South Atlantic 
Atlantic Ocean surge, BCM implementation, and sea level fluctuations throughout the Quaternary. Notable examples of Brazilian geodiversity of scientific, geotouristic, economic, and educational interest were identified. These included submarine volcanic mounts, fracture zones associated with the mid-oceanic ridge, evaporite movement through the sedimentary package, paleochannels, deltas, canyons, turbidite systems, mineral deposits (biogenic limestone, marine granulated, and polymetallic rock salt), and areas susceptible to mass movements along submarine slopes as a result of geological processes (i.e., hazards).

Some supporting relationships between geodiversity and local biodiversity were identified. For example, the most important reef formation in the South Atlantic developed on a platform that was extended by volcanic effusions in the northern portion of the study area $(\mathrm{Ab}$ rolhos Bank). Additionally, the development of bioconstructions on elevated areas of the Vitória - Trindade Ridge favor the appearance of corridors for coastal species that can use them, because of their shallow depth and proximity to ridge banks and seamounts, to travel long distances from the coast.

Overall, this manuscript is intended to aid in the generation and dissemination of knowledge about Brazilian marine geodiversity and to provide support for additional studies aimed at the evaluation, conservation, utilization, and management of abiotic marine resources. Furthermore, the proposed characterization model can be applied to other regions of the Brazilian continental shelf and adjacent areas.

The information obtained through geodiversity surveys, when paired with biotic, social, and legal information, can play an important role in seabed planning activities, thus facilitating geoconservation and the management

of conflicts of interest. It also constitutes the first step for selecting representative areas to study Earth's geo-

\section{References}

Almeida, F.F.M. (2002) - Ilha de Trindade: registro de vulcanismo cenozoico no Atlântico sul. In: C. Schobbenhaus, D. A, Campos, E. T. Queiroz, M. Winge, \& M. L. C. Berbert-Born (eds.), Sítios Geológicos e Paleontológicos do Brasil, Volume 1, pp. 369-377, DNPM/CPRM/SIGEP, Brasília, Distrito Federal, Brasil. ISBN: 8574990774. Available on-line at http://sigep. cprm.gov.br/sitios.htm - Voll.

Alves, E.C.; Maia, M.; Sichel, S.E.; Campos, C.M.P. de (2006) Zona de fratura de Vitória-Trindade no oceano Atlântico sudeste e suas implicações tectônicas. Revista Brasileira de Geofisica, 24(1):117-127. DOI: 10.1590/S0102-261X2006000100009.

Booth, K.A.; Brayson, J. (2011) - Geology, landscape and human interactions: examples from the Isle of Wight. Proceedings of the Geologists' Association, 122(5):938-948. DOI: 10.1016/ j.pgeola.2011.01.004

Brilha, J. (2005) - Patrimônio Geológico e Geoconservação: A Conservação da Natureza na sua Vertente Geológica. 190p., Palimage Editores, Braga, Portugal. ISBN: 9728575904. logical history. Examination of resource management measures in geologically diverse areas and protection of such areas for present and future generations is necessary since the use of the continental shelf and adjacent areas for various purposes is increasing. Moreover, information obtained through geodiversity surveys can foster the creation of specific legislation for preserving geodiversity and biodiversity, as in Europe.

Issues such as the inventory, assessment, and conservation of geoheritage sites need to be further researched. There are several methods for the quantification and selection of geoheritage sites (geosites) in continental areas, which depend on the degree of scientific knowledge, representation (diversity and rarity), accessibility, educational value, extent of preservation, and interest level (local, regional, national, and global). However, there is a lack of such studies that consider these aspects in marine environments. Hence, more such studies in marine environments would be valuable.

\section{Appendix}

Supporting Information associated with this article is available online at http://www.aprh.pt/rgci/pdf/rgci-565_Ranieri_SupportingInformation.pdf

\section{Acknowledgements}

This study was conducted under the Geodiversity Surveying Program of the Geological Survey of Brazil and the Brazilian Coastal and Oceanic Islands Project: Genesis, Geodiversity, and Environmental Control, which is coordinated by the Laboratory of Coastal Geology, Sedimentology, and Environment of the National $\mathrm{Mu}-$ seum/UFRJ-Federal University of Rio de Janeiro. The authors are thankful to the Brazilian Navy, who through the Center of DHN and BANPETRO (Banco de Dados de Petróleo e Gás Natural [Database of Oil and Natural Gas]) provided the data, and to CAPES (Coordenação de Aperfeiçoamento de Pessoal de Nivel Superior [Coordination for the Improvement of Higher Education]) for granting the scholarship aid for the research conducted within the framework of the Graduate Studies Program in Geology (MSC), Geosciences Institute of the Federal University of Rio de Janeiro.

Brooks, A.J.; Kenyon, N.H.; Leslie, A.; Long, D.; Gordon, J.E. (2013) - Characterizing Scotland's marine environment to define search locations for new Marine Protected Areas. Part 2: The identification of key geodiversity areas in Scottish waters. 209p., Commissioned Report No. 432, Scottish Natural Heritage, Report 431, Inverness, U.K. Available on-line at http://www.snh.org.uk/pdfs/publications/commissioned_reports/432.pdf

Burek, C.V.; Ellis, N.V.; Evans, D.H.; Hart, M.B.; Larwood, J.G. (2012) - Marine geoconservation in the United Kingdom. Proceedings of the Geologists' Association, 124(4):581-592. DOI: 10.1016/j.pgeola.2012.10.003.

Castro, J.W. de A. (2010) - Ilhas oceânicas da Trindade e Fernando de Noronha, Brasil: Uma visão da Geologia Ambiental. Revista de Gestão Costeira Integrada / Journal of Integrated Coastal Zone Management, 10(3):303-319. DOI: 10.5894/rgci170

Castro, J.W.A.; Antonello, L.L. (2006) - Geologia das ilhas oceânicas brasileiras. In: Alves, R.J.V.; Castro, J.W. de A. (eds.), Ilhas Oceânicas Brasileiras: Da Pesquisa ao Manejo, pp. 29- 
57, Ministério do Meio Ambinte, Secretaria de Biodiversidade e Florestas, Brasília, DF, Brasil.

Cavalcanti, V.M.M. (2011) - Plataforma Continental: A Última Fronteira da Mineração Brasileira. 104p., Departamento Nacional de Produção Mineral (DNPM), Brasília, DF, Brasil. ISBN: 978-85232059703. Available on-line at http://www.dnpm. gov.br/mostra_arquivo.asp?IDBancoArquivoArquivo $=5579$.

Cordani, U.G. (1970) - Idade do vulcanismo do oceano Atlântico sul. Boletim IGA (ISSN: 0100-3925), 1:9-75. Instituto de Geociências, Universidade de São Paulo, SP, Brasil. Available on-line at http://ppegeo.igc.usp.br/pdf/biga/v1/v1a02.pdf

CPRM (2008) - Geologia da plataforma continental jurídica brasileira e áreas oceânicas adjacentes: dados organizados em sistema de informações geográficas. Ministério de Minas e Energia, Companhia de Pesquisa de Recursos Minerais, Brasília, D.F., Brasil. Available on-line at http://www.cprm.gov.br/ publique/cgi/cgilua.exe/sys/start.htm?infoid=1060\&sid=27.

Dias, G.T. de M.; Robrini, M.; Freire, J.S.S.; Figueiredo, A. (2008) - Mapa de sedimentos superficiais da plataforma continental brasileira. In: CPRM (org.), Geologia da Plataforma Continental Jurídica Brasileira e Áreas Oceânicas Adjacentes: Dados Organizados em Sistema de Informações Geográficas. Ministério de Minas e Energia, Companhia de Pesquisa de Recursos Minerais, Brasília, DF, Brasil [DVD-ROM].

Faugères, J.-C.; Lima, A. L.; Massé, L.; Zaragosi, S. (2002) - The Columbia channel-levee system: a fan drift in the southern Brazil basin. In: D. A. V. Stow et al. (eds), Deep-water contourite systems: modern drifts and ancient series, seismic and sedimentary characteristics, 22, pp. 223-238, Geological Society Memoir, London, U.K.. ISBN: 978-1862390928. Available online at http://www.epoc.u-bordeaux.fr/indiv/Zaragosi/Faugeres _et_al 2002b.pdf

França, A.M.C. (1979) - Geomorfologia da margem continental leste brasileira e das bacias oceânicas adjacentes. In: H. A. F. Chaves (ed.), Geomorfologia da Margem Continental Brasileira e das Áreas Oceânicas Adjacentes: Relatório Final, pp. 89-127, Petrobrás, Rio de Janeiro, RJ, Brasil.

Felton, A. (2010) - Marine geotourism development at the Sapphire Coast Marine Discovery Center, Eden, N.S.W. In: Symposium on Geodiversity, Geological Heritage and Geotourism, Sydney, Austrália. Abstract available on-line at http://www.resources.nsw. gov.au/ data/assets/pdf file/0004/359428/GGHG_2010_Program_Abstr acts.pdf

Fodor, R.V.; Hanan B.B. (2000) - Geochemical evidence for the Trindade hotspot trace: Columbia seamount ankaramite. Lithos, 51(4):293-304. DOI: 10.1016/S0024-4937(00)00002-5

Gasparini, J.L.; Floeter, S.R. (2001) - The shore fishes of Trindade island, western South Atlantic. Journal of Natural History, 35(11):1639-1656. DOI: 10.1080/002229301317092379

Gordon, J.E.; Barron, H.F. (2011) - Scotland's geodiversity: development of the basis for a national framework. 155p., Commissioned Report No ${ }^{\circ}$. 417, Scottish Natural Heritage, Edinburgh, U.K. ISBN: 978-1853977046. Available on-line at http://www.snh. org.uk/pdfs/publications/commissioned_reports/417.pdf

Gray, M. (2004) - Geodiversity: Valuing and Conserving Abiotic Nature. 508p., John Wiley \& Sons, New York, NY, U.S.A. ISBN: 978-0470742150.

Gray, M. (2008) - Geodiversity: the origin and evolution of a paradigm. In: C. V. Burek \& C.D. Prosser (eds.), The History of Geoconservation, pp. 31-36, Geological Society Special Publications, v. 300, Geological Society of London, London. DOI: 10.1144/SP300.4.

Hansen, M.A.F.; Viramonte, J.G.; Troian, F.L.; Mizusaki, A.M.P.; Becchio, R.; Fensterseifer, H.C. (1998) - Nuevas edades para el volcanismo de lãs isles Trindade y Martin Vaz, Brasil. Sixth In- ternational Meeting: Colima Volcano, México, 26.1-28.1, Abstracts, 125, Mexico.

Kaskela, A.M.; Kotilainen, A.T.; Al-Hamdani, Z.; Leth, J.O.; Reker, J. (2012) - Seabed geomorphic features in a glaciated shelf of the Baltic sea. Estuarine, Coastal and Shelf Science, 100:150 161. DOI: 10.1016/j.ecss.2012.01.008.

Leão, Z.M.A.N.; Abrolhos, B.A. (2002) - O complexo recifal mais extenso do Atlântico Sul. In: C. Schobbenhaus, D. A. Campos, E. T. Queiroz, M. Winge \& M. L. C. Berbert-Born (eds.), Sitios Geológicos e Paleontológicos do Brasil, 1:345-359, Departamento Nacional de Produção Mineral (DNPM) /Serviço Geológico do Brasil (CPRM) / Comissão Brasileira de Sítios Geológicos e Paleobiológicos (SIGEP), Brasília, DF, Brasil. ISBN: 85-85258-03-9. Available on-line at http://sigep.cprm. gov.br/sitio090/sitio090.pdf

Larsonneur, R. (1977) - La Cartographie des Dépôt Meubles sur le plateau continental français: méthode mise au point et utilisée em Manche. Journal de Recherche Océanographique (ISSN: 0397-5347), 2:34-39, Union des Océanographes de France, Institut Océanographique, Paris, France.

Lima, E.A.; Nunes, J.C.; Costa, M.P.; Machado, M. (2014) - Basis for the geological heritage management in the Azores Archipelago (Portugal). Journal of Integrated Coastal Zone Management, 14(2):301-319. DOI: 10.5894/rgci484.

Maia, M.A.M. (2013) - Geodiversidade das áreas adjacentes à cadeia submarina de Vitória-Trindade: Construção e aplicação de um modelo de compartimentação em macroescala do assoalho oceânico. 153p., Dissertação de Mestrado, Universidade Federal do Rio de Janeiro, Instituto de Geociênciais, Rio de Janeiro, RJ, Brasil. Available on-line at http://www.cprm.gov .br/publique/media/Diss_Adelaide_Maia.pdf

Maia, M.A.M.; Castro, J.W. de A.; Silva, C.R. (2012) - Proposta para levantamento da geodiversidade marinha da cadeia de montes vulcânicos de Vitória-Trindade. In: LXVI Congresso Brasileiro de Geologia, Santos, SP, Anais [DVD-ROM].

Mansur, K.L.; Carvalho, I. de S. (2011) - Characterization and valuation of the geological heritage identified in the Pero dune field, state of Rio de Janeiro, Brazil. Geoheritage, 3:97-15. DOI: 10.1007/s12371-011-0036-y.

Mohriak, W.U. (2008) - Tectônica de sal autóctone e alóctone na margem sudeste brasileira. In: W. U. Mohriak, P. Szatmari \& S. M. Couto Anjos (eds.), Sal: Geologia e Tectônica, pp. 300-313, Beca/Petrobras, São Paulo, SP, Brasil. ISBN: 8587256491.

Motoky, A.; Motoky, K.F.; Melo, D.P. (2012) - Caracterização da morfologia submarina da cadeia Vitória-Trindade e áreas adjacentes-ES, com base na batimetria predita do topo versão 14.1. Revista Brasileira de Geomorfologia (ISSN: 2236-5664), 13(2):151-170, União da Geomorfologia Brasileira, São Paulo, SP, Brasil Available on-line at http://www.lsie.unb.br/rbg /index.php/rbg/article/viewFile/195/292.

Nascimento, M.A.L do.; Ruchkys, Ú.A.; Mantesso-Neto, V. (2008) - Geodiversidade, Geoconservação e Geoturismo: Trinômio Importante para a Proteção do Patrimônio Geológico. 82p., Sociedade Brasileira de Geologia, São Paulo, SP, Brasil. ISBN: 978-8588769564.

Nunes, J.C.; Lima, E.A.; Medeiros, S. (2007) - Os Açores, ilhas de geodiversidade: o contributo da ilha de Santa Maria. Açoreana: revista de estudos açoreanos (ISSN: 0874-0380), Supl. 5:74111, Sociedade de Estudos Açorianos Afonso Chaves, Angra do Heroísmo Available on-line at http://www.db.uac.pt/pdf/ainic/42.pdf

Palma, J.J.C.; Tavares, A.A.L.A.; Jeck, I.K. (2008) - Mapa fisiográfico da plataforma continental jurídica brasileira e áreas oceânicas adjacentes, escala 1:2.500.000. In: Kaiser Gonçalves de Souza (coord.), Geologia da Plataforma Continental Jurídica Brasileira e Áreas Oceânicas Adjacentes: Dados Organizados 
em Sistema de Informações Geográficas. Ministério de Minas e Energia, Companhia de Pesquisa de Recursos Minerais, Brasília, DF, Brasil [DVD-ROM].

Palma, J.J.C. (1979) - Mapa de Recursos Minerais Superficiais da Plataforma Continental Brasileira. In: H. A. F. Chaves (ed.), Recursos Minerais da Margem Continental Brasileira e das Áreas Oceânicas Adjacentes: Relatório Final. 9pp., Petrobrás, Centro de Pesquisas e Desenvolvimento Leopoldo A. Miguez de Mello (CENPES), Divisão de Informação Técnica e Propriedade Industrial (DINTEP), Rio de Janeiro, RJ, Brasil.

Palma, J.J.C.; França, A.M.C. (1979) - Mapa Fisiográfico. In: Chaves, H.A.F. (ed.), Geomorfologia da Margem Continental Brasileira e das Áreas Oceânicas Adjacentes: Relatório Final, Rio de Janeiro, pp. 89-127, PETROBRAS/CENPES/DINTEP, Rio de Janeiro, RJ, Brasil.

Palma, Jorge J. C.; Pessanha, Ivo B. M.. (2000) - Dépositos ferromanganesíferos de oceano profundo. Revista Brasileira de Geofisica, 18(3), 433-446. DOI: 10.1590/S0102-261X2000000 300015 .

Pires, G.L.C.; Mansur, K.L.; Bongliolo, E.M. (2013) - Geoconservação da Ilha da Trindade: Principais aspectos e Potencial de Uso. Anuário do Instituto de Geociências - UFRJ (ISSN: 01019759), Universidade Federal do Rio de Janeiro, Centro de Ciências Matemáticas e da Natureza, Instituto de Geociências, Rio de Janeiro RJ, Brasil. Available on-line at http://www.anuario. igeo.ufrj.br/2013_2/2013_2_96_104.pdf.

Rovere, A.; Vacchi, M.; Parravicini, V.; Morri, C.; Bianchi, C.N.; Firpo, M. (2010) Bringing geoheritage underwater: methodological approaches to evaluation and mapping. In: G. RegoliniBissig, G. \& E. Reynard (eds), Géovisions, 35:65-80. DOI: 10.1007/s12665-010-0824-8.

Schmitt, R.S.; Mansur, K.L. (2001) - Os Caminhos Geológicos do Estado do Rio de Janeiro - a experiência de Armação dos Búzios. In: VII Simpósio de Geologia do Sudeste, Rio de Janeiro, Boletim de Resumos, Rio de Janeiro, RJ, Brazil.
Schreiner, S.; Souza, M.B.F.M. de; Migliorelli, J.P.R. (2009) Modelo digital da geomorfologia do fundo oceânico do centro-

sul da bacia do Espírito Santo e norte da bacia de Campos. Boletim de Geociências da Petrobras (ISSN: 0102-9304), 17(2):365-369, Rio de Janeiro, RJ, Brasil Available on-line at http://vdpf.petrobras.com.br/vdpf/PDFHighlightServlet.svlt?acao=pdf\& codigoArtigo $=2631$

Shepard, F.P. (1954) - Nomenclature based on sand-silt-clay rations. Journal of Sedimentary Petrology, 24(3):151-158. DOI: 10.1306/D4269774-2B26-11D7-8648000102C1865D

Silveira, I.C.A.; Schmidt, A.C.K.; Campos, E.J.D.; de Godoi, S.S.; Ikeda, Y. (2000) - A Corrente do Brasil ao Largo da Costa Leste Brasileira. Revista Brasileira de Oceanografia, 48(2):171-183, São Paulo, SP, Brazil. DOI: 10.1590/S1413-77392000000 200008.

Skolotnev, S.G.; Bylinskaya, M.A.; Golovina, L.A.; Ipat'Eva, I.S. (2011) - First data on the age of rocks from the central part of the Vitoria-Trindade ridge (Brazil Basin, South Atlantic). Doklady Earth Sciences, 437(1):316-322. DOI: 10.1134/ S1028334X11030093.

Suguio, K.; Martin, L.; Dominguez, J.M.L. (1982) - Evolução da planícies costeira do rio Doce (ES) durante o quaternários: Influência das flutuações do nível do mar. Influência das flutuações do nível do mar. In: 4 Simpósio do Quaternário no Brasil, Rio de Janeiro, pp.93-116, SBG, Rio de Janeiro, RJ, Brasil.

Thomaz Filho, A.; Rodrigues, A.L. (1999) - O alinhamento de rochas alcalinas Poços de Caldas-Cabo Frio (RJ) e sua continuidade na cadeia Vitória-Trindade. Revista Brasileira de Geociências (ISSN: 2317-4692), 29(2):189-194, Sociedade Brasileira de Geologia, São Paulo, SP, Brasil. Available on-line at http://rbg.sbgeo.org.br/index.php/rbg/article/view/682. 